Stanistaw Prutis

\title{
Dobór instrumentów prawnych służących wsparciu rozwoju obszarów wiejskich
}

1. System wsparcia rozwoju obszarów wiejskich ze środków Unii Europejskiej funkcjonuje już w naszym kraju w kolejnej, drugiej edycji. Horyzont czasowy pierwszej edycji wyznaczał Plan Rozwoju Obszarów Wiejskich w latach 2004-2006 ${ }^{1}$. Konstrukcje prawne i mechanizmy wdrażania działań wspierających regulowało w tym okresie rozporządzenie Rady (WE) nr 1257/1999 z dnia 17 maja 1999 r. w sprawie wsparcia rozwoju obszarów wiejskich z Europejskiego Funduszu Orientacji i Gwarancji Rolnej ${ }^{2}$, a w ustawodawstwie krajowym - ustawa z dnia 28 listopada 2003 r. o wspieraniu rozwoju obszarów wiejskich ze środków pochodzących z Sekcji Gwarancji Europejskiego Funduszu Orientacji i Gwarancji Rolnej ${ }^{3}$ oraz wydane, w wykonaniu delegacji ustawowej, rozporządzenia Rady Ministrów określające szczegółowe warunki i tryb udzielania pomocy finansowej na działania objęte planem, a także przestrzenny zasięg wdrażania tych działań4.

Kolejna, aktualna edycja wsparcia rozwoju obszarów wiejskich swoim horyzontem czasowym sięga do roku 2013 (Program Rozwoju Obszarów Wiejskich na lata 2007-20135), a jego konstrukcję prawną regulują przepisy rozporządzenia Rady (WE) nr 1698/2005 z dnia 20 września 2005 r. w sprawie wsparcia rozwoju obszarów wiejskich przez Europejski Fundusz Rolny na rzecz Rozwoju Obszarów Wiejskich (EFRROW) ${ }^{6}$. W krajowym porządku prawnym system wsparcia określają przepisy ustawy z dnia 7 marca 2007 r. o wspieraniu rozwoju obszarów wiejskich z udziałem środków Europejskiego Funduszu Rolnego na Rzecz Rozwoju Obsza-

Stanowiący załącznik do obwieszczenia Ministra Rolnictwa i Rozwoju Wsi z dnia 15 listopada 2004 r. w sprawie planu rozwoju obszarów wiejskich (M.P. nr 56, poz. 958).

Dz.Urz. UE.L.99.160.80.

Dz.U. nr 229, poz. 2273.

Przykładowo wskazać można rozporządzenie Rady Ministrów z dnia 30 kwietnia 2004 r. w sprawie szczegółowych warunków i trybu udzielania pomocy finansowej na uzyskiwanie rent strukturalnych objętej planem rozwoju obszarów wiejskich (Dz.U. Nr 114, poz. 1191).

5 Program ten stanowi, tak jak i program poprzedni, załącznik do obwieszczenia Ministra Rolnictwa i Rozwoju Wsi z dnia 12 października 2007r. (M.P. 07.94.1035).

6 Dz.Urz. UE.L. 277, 21.10.2005, s. 1-40 z późn. zm.
} 
rów Wiejskich ${ }^{7}$, a także rozporządzeń wykonawczych Ministra Rolnictwa i Rozwoju Wsi.

Przy zachowaniu zasadniczych konstrukcji wdrażania wsparcia dla obszarów wiejskich w regulacji prawnej zaszły jednak istotne zmiany. Istotnym novum w regulacji prawa europejskiego, w stosunku do starej regulacji rozporządzenia 1257/1999, jest wskazanie w rozporządzeniu 1698/2005 priorytetów, którym mają zadośćuczynić poszczególne instrumenty wspierania obszarów wiejskich przypisane do poszczególnych tzw. osi. Priorytety nakreślone na poziomie Wspólnoty polegają na określeniu celów, do osiągnięcia których przyczyniać się ma wsparcie rozwoju obszarów wiejskich, a pod pojęciem „osi” rozumie się spójną grupę środków, których wdrażanie prowadzi bezpośrednio do osiągnięcia szczegółowych celów i przyczynia się do realizacji jednego lub więcej celów określonych w art. 4 rozporządzenia nr 1698/2005. Zgodnie z powołanym przepisem, wsparcie rozwoju obszarów służyć ma osiągnięciu następujących celów (priorytetów):

a) poprawie konkurencyjności rolnictwa i leśnictwa poprzez wspieranie restrukturyzacji, rozwoju i innowacji,

b) poprawie środowiska naturalnego i terenów wiejskich poprzez wspieranie gospodarowania gruntami,

c) poprawie jakości życia na obszarach wiejskich oraz popierania różnicowania działalności gospodarczej.

W ramach priorytetów nakreślonych na poziomie Wspólnoty (cele i osie), państwa członkowskie mają możliwość wyboru konkretnego instrumentarium, którego stosowanie służyć może rozwiązaniu problemów rolnictwa danego państwa członkowskiego i położenia nacisku na elementy specyficzne wymagające szczególnego wsparcia. Zarys instrumentów znajduje się w opracowanych na poziomie państw członkowskich krajowych planach strategicznych, w oparciu o które opracowywane są programy rozwoju obszarów wiejskich. W uzasadnieniu do rozporządzenia 1698/2005 stwierdza się, że państwa członkowskie przy programowaniu rozwoju obszarów wiejskich powinny uwzględniać priorytety wspólnotowe i krajowe, a także inne polityki wspólnotowe, w szczególności politykę rynku rolnego i politykę spójności.

Novum obecnej edycji wsparcia rozwoju obszarów wiejskich to nie tylko określenie celów i osi wsparcia, lecz także nałożenie przepisem art. 17 rozporządzenia 1698/2005 wymagania co do przeznaczenia środków pochodzących z budżetu UE na poszczególne osie. Wkład finansowy Wspólnoty w każdy z trzech celów określonych w art. 4 obejmuje przynajmniej 10\% całkowitego wkładu EFFROW w program dla osi 1 i 3, oraz przynajmniej 25\% całkowitego wkładu EFFROW w program 
dla osi 2; kwota równa przynajmniej 5\% całkowitego wkładu EFFROW w program rezerwowana jest dla osi 4. Wyjaśnić należy, iż osie 1-3 odpowiadają celom wsparcia określonym w art. 4 rozporządzenia 1698/2005, natomiast specyficzny charakter ma oś 4. I tak:

Oś 1 - to: Poprawa konkurencyjności sektora rolnego i leśnego (art. 20-35 rozporządzenia);

Oś 2 - to: Poprawa środowiska naturalnego i terenów wiejskich (art. 36-51 rozporządzenia);

Oś 3 - to: Jakość życia na obszarach wiejskich i różnicowanie gospodarki wiejskiej (art. 52-60 rozporządzenia);

Oś 4 - to: Leader (art. 61-65 rozporządzenia), która nie jest odpowiednikiem konkretnego celu wsparcia określonego w art. 4 rozporządzenia, lecz stanowi wyraz wzmocnienia inicjatyw oddolnych i aktywizacji społeczności lokalnej na wsi, zakładając tworzenie sieci partnerstw lokalnych i lokalnych strategii rozwoju (art. 61 rozporządzenia).

Regulacja wsparcia rozwoju obszarów wiejskich na szczeblu Wspólnoty Europejskiej obejmuje zatem określenie generalnych celów wsparcia (art. 4 rozporządzenia 1698/2005), sprecyzowanie spójnych grup środków służących do osiągania tych celów (osie), a także wyznaczenie podstawowych proporcji rozdziału środków finansowych, służących sfinansowaniu poszczególnych osi (art. 17 rozporządzenia).

Instrumentarium powyższe adresowane jest do poszczególnych krajów - członków Unii, a precyzyjnie rzecz biorąc - do organów odpowiedzialnych za przygotowanie Programu Rozwoju Obszarów Wiejskich na lata 2007-2013, czyli w naszym przypadku do Ministra Rolnictwa i Rozwoju Wsi. PROW 2007-13, choć ma tylko rangę prawną uchwały Rady Ministrów, jest niesłychanie ważnym dokumentem, albowiem zawiera rozstrzygnięcia co do wyboru poszczególnych działań, należących do każdej z 4 osi, a także określa wstępne alokacje środków finansowych na poszczególne działania w latach 2007-13, co determinuje zakres i dynamikę czasową uruchomienia poszczególnych działań.

Typowy opis działania wybranego do realizacji w ramach danej osi zawiera następujące elementy: nazwa działania (np. Modernizacja gospodarstw rolnych), kod działania, podstawa prawna (odpowiedni przepis rozporządzenia nr 1698/2005, w przypadku „Modernizacji...” jest to art. 26 rozporządzenia), uzasadnienie wyboru działania, zakres pomocy, beneficjent, kryteria dostępu, forma i wysokość pomocy, poziom pomocy, zasięg geograficzny, szacowana liczba beneficjentów, wskaźniki monitorowania. Opis poszczególnych działań wspierających rozwój obszarów wiejskich, dokonany w PROW, nie ma charakteru normatywnego, nie stwarza więc uprawnień podmiotowych ani nie nakłada obowiązków na organy. Co wszakże wymaga podkreślenia, to fakt, iż określenie niektórych elementów działania, takich 
jak oznaczenie beneficjenta i kryteriów dostępu do danej formy pomocy, określenie zakresu i wysokości pomocy, wskaźników monitorowania, rozstrzygało merytorycznie kwestie będące później przedmiotem regulacji w rozporządzeniach Ministra Rolnictwa i Rozwoju Wsi w sprawie szczegółowych warunków trybu przyznawania pomocy finansowej w ramach poszczególnej kategorii działania. Regulacje prawne nie odbiegają od opisu działania dokonanego w PROW 2007-13. A zatem PROW 2007-13 stanowi swoisty pomost pomiędzy ogólnymi unormowaniami prawa europejskiego a krajowymi regulacjami służącymi wdrożeniu poszczególnych działań mających na celu rozwój obszarów wiejskich.

2. Formalne zmiany w ustawodawstwie krajowym to nie tylko zastąpienie regulacji ustawowej z dnia 28 listopada 2003 r. regulacją z 7 marca 2007 r., lecz także zmiany w sposobie legislacji omawianej materii. Zmiany w sposobie legislacji polegają na rozszerzeniu przedmiotu regulacji objętej bezpośrednio przepisami rangi ustawowej, dotyczą doboru instrumentów prawnych (decyzja administracyjna czy umowa cywilnoprawna) służących wdrażaniu poszczególnych działań wspierających, wprowadzają istotne modyfikacje procedur prawnych organizujących udzielanie wsparcia oraz kontrolę prawidłowości wykorzystania przyznanych środków finansowych.

Przedmiotem bezpośredniej regulacji ustawowej w pierwszej ustawie (z 28.11.2003 r.) były podstawowe rozwiązania konstrukcyjne i procedury wspierania rozwoju obszarów wiejskich. Regulacja nie była zbyt obszerna (w sumie 9 artykułów ustawy), a uzupełniały ją rozporządzenia wykonawcze Rady Ministrów określające szczegółowe warunki i tryb udzielania, wstrzymywania, zawieszania, zwracania i zmniejszania pomocy finansowej na działania objęte planem rozwoju obszarów wiejskich. Każde z ośmiu zadań było przedmiotem odrębnej regulacji aktem prawnym rangi rozporządzenia Rady Ministrów. Legislacja drugiej edycji wsparcia rozwoju obszarów wiejskich jest znacznie bogatsza. Rozbudowana została materia będąca przedmiotem regulacji bezpośrednio ustawą (art. 1-37 ustawy z 7.03.2007 r.). Delegację do wydania rozporządzeń wykonawczych, w miejsce dotychczas uprawnionej Rady Ministrów, otrzymał minister właściwy do spraw rozwoju wsi. Przyjęto zasadę, iż każdy z kierunków działania w ramach wsparcia rozwoju obszarów wiejskich regulowany jest odrębnym rozporządzeniem ministra, co przy znacznym rozszerzeniu kierunków i działań w ramach wsparcia powoduje, że łączna liczba rozporządzeń wykonawczych przekracza 20.

Każdy ze stosownych modeli legislacji ma swoje plusy i minusy. Szeroki zakres bezpośredniej regulacji ustawowej stanowi gwarancję stabilności rozwiązań prawnych. Jednakże w przypadku konieczności zmian (a ustawa z dnia 7.03.2007 r. była już dwukrotnie nowelizowana) uruchomienie procedury parlamentarnej, łącznie z podpisem prezydenta, wymaga woli politycznej i czasu. Podobnie można oceniać 
wybór rangi prawnej wykonawczego aktu normatywnego - rozporządzenie Rady Ministrów czy rozporządzenie ministra resortowo właściwego. Obciążenie rządu obowiązkiem wydania ponad 20-stu rozporządzeń wykonawczych nie wydaje mi się zadaniem zbyt absorbującym dla rządowych służb legislacyjnych. Wybrano wszakże formę rozporządzenia wykonawczego ministra właściwego do spraw rozwoju wsi. Terminowe przygotowanie aktu wykonawczego ma o tyle istotne znaczenie, że bez rozstrzygnięć szczegółowych zawartych w akcie wykonawczym wdrażanie poszczególnych kierunków wsparcia rozwoju obszarów wiejskich jest praktycznie niemożliwe. Brak rozporządzeń wykonawczych lub opóźnienie ich wejścia w życie może decydować o możliwości wykorzystania środków przeznaczonych na poszczególne kierunki wsparcia. Ustawa z dnia 7.03.2007 r. weszła w życie z dniem ogłoszenia, tj. 11.04.2007 r., natomiast rozporządzenia wykonawcze Ministra Rolnictwa i Rozwoju Wsi dotyczące poszczególnych działań były wydane w ciągu roku 2007 (8 rozporządzeń) oraz w roku 2008 (16 rozporządzeń); ostatnie z rozporządzeń zostało wydane dnia 17.07.2008 r., ${ }^{8}$ a więc ponad rok od wejścia w życie ustawy.

Powierzenie kompetencji wydawania rozporządzeń wykonawczych ministrowi właściwemu do spraw rozwoju wsi nie budzi zastrzeżeń, gdy chodzi o działania wspierające rozwój obszarów wiejskich poprzez poprawę konkurencyjności sektora rolnego i leśnego (oś 1). Wydaje się wszakże uzasadniony postulat, aby akty normatywne regulujące wsparcia w ramach osi 2 - poprawa środowiska naturalnego i terenów wiejskich - wydawane były przez ministra rolnictwa „w porozumieniu” z ministrem ochrony środowiska, natomiast rozporządzenia wykonawcze regulujące działania w ramach osi 3 - różnicowanie gospodarki wiejskiej i poprawa jakości życia na wsi - wymagałyby współdziałania ministra rolnictwa oraz ministra gospodarki. Postulat współdziałania kilku ministrów przy opracowaniu regulacji prawnej poszczególnych działań wspierających rozwój obszarów wiejskich podyktowany jest faktem, iż regulowana materia należy do przedmiotu zainteresowania kilku resortów, które powinny mieć wpływ na regulację prawną udzielania wsparcia, szczególnie w sytuacji, gdy w koalicyjnym rządzie poszczególni ministrowie reprezentują różne siły polityczne.

Kolejny problem z zakresu doboru instrumentów prawnych to kwestia stopnia szczegółowości regulacji prawnej rozporządzeń wykonawczych. Pamiętać należy, iż rozporządzenie ministra rolnictwa i rozwoju wsi stanowi trzeci szczebel w hierarchii źródeł prawa. Zgodnie z zasadami dobrej legislacji, przepisy prawa krajowego nie powinny powtarzać przepisów prawa europejskiego, a przepisy rozporządzeń wykonawczych nie powinny dublować zapisów ustawowych. Względy pragmatyczne, a w szczególności trudności z dotarciem do prawa europejskiego przez adresaoraz wypłaty pomocy finansowej w ramach działania „Tworzenie i rozwój mikroprzedsiębiorstw” objętego Programem Rozwoju Obszarów Wiejskich na lata 2007-2013 (Dz.U. Nr 139, poz. 883). 
tów tych norm - rolników, przemawiają jednak za tym, aby podstawowe przesłanki udzielenia wsparcia oraz konstrukcje prawne służące jego realizacji znalazły swoje miejsce także w prawie krajowym. Ze względu na niezbyt wysoki poziom kultury prawnej u rolników - beneficjentów pomocy, a także niski poziom obsługi prawnej ${ }^{9}$ jednostek organizacyjnych Agencji Restrukturyzacji i Modernizacji Rolnictwa udzielających wsparcia, wskazane jest, aby rozporządzenia wykonawcze w sposób raczej szczegółowy i rozbudowany regulowały obowiązki organów oraz uprawnienia rolników - beneficjentów wsparcia. Zauważyć wszakże należy, iż stopień szczegółowości regulacji prawnej powinien być zróżnicowany w zależności od mechanizmu prawnego zastosowanego przy udzieleniu wsparcia. Jak wiadomo, pomoc w ramach poszczególnych działań jest przyznawana bądź w drodze decyzji administracyjnej, bądź na podstawie umowy zawieranej z beneficjentem. Wydaje mi się, iż można wyrazić pogląd, że regulacja prawna tych działań, w których wsparcie jest przyznawane na podstawie umowy, powinna pozostawić szerszy margines swobody do uregulowania wzajemnych zobowiązań na zasadzie swobody umów jako wiodącej zasadzie prawa cywilnego.

W tym miejscu dochodzimy do pytania głównego, zasadniczego dla rozważań na temat doboru instrumentów prawnych służących wdrażaniu działań wspierających rozwój obszarów wiejskich. Dobór polega na potrzebie wyboru - decyzja administracyjna czy umowa cywilnoprawna, jako mechanizm organizujący transfer środków służących wsparciu poszczególnych działań. Jak twierdzą wybitni znawcy prawa, nie ma spraw ze swej istoty cywilnych lub administracyjnych, a wola ustawodawcy decyduje o tym, czy konkretna sprawa będzie załatwiona w trybie cywilnoprawnym czy administracyjnym ${ }^{10}$. „Nie znaczy to oczywiście, by ustawodawca mógł sobie dobierać instrumenty prawne w sposób całkowicie dowolny. Musi się liczyć zawsze z prawami rozwoju społecznego i realnym układem stosunków" ${ }^{11}$. W pierwszej edycji wsparcia rozwoju obszarów wiejskich, na 8 kategorii zadań wspierających w 7-miu, pomoc była udzielana w drodze decyzji administracyjnej; jedynie pomoc techniczna dla jednostek organizacyjnych i organów realizujących zadania udzielona była na podstawie umowy cywilnoprawnej. Obecnie realizowane wsparcie rozwoju obszarów wiejskich, przy znacznej rozbudowie kierunków wsparcia, reguluje udzielenie pomocy na podstawie decyzji administracyjnej w 11stu przypadkach. Umowa jest instrumentem organizującym wsparcie w 12-stu rodzajach działań wspierających. O wyborze mechanizmu prawnego organizującego konkretny rodzaj wsparcia zdecydował sam ustawodawca, określając bezpośrednio w ustawie działania, w których pomoc jest przyznawana w drodze decyzji administracyjnej (art. 20 ustawy) oraz działania, kiedy pomoc jest przyznawana na podsta-

11 A. Stelmachowski, Zarys teorii prawa cywilnego, Warszawa 1998, s. 15. 
wie umowy (art. 22 ustawy). W uzasadnieniu ustawy brak jest szerszego wyjaśnienia rozstrzygnięć podjętych w tym zakresie.

Ocena adekwatności stosownych instrumentów prawnych wymaga pogłębiania analizy teoretycznej a przede wszystkim badań empirycznych, w jakim stopniu zastosowane mechanizmy realizują cele stawiane przed instytucją wsparcia rozwoju obszarów wiejskich. W tym miejscu wskazać można jedynie na pewne generalne prawidłowości. Wsparcie rozwoju obszarów wiejskich polega na udzieleniu pomocy finansowej dużej liczbie beneficjentów (głównie rolników) w sytuacji ograniczonej ilości środków. Udzielenie pomocy wymaga sprawdzenia przesłanek jej przyznawania oraz wydania szybkiego rozstrzygnięcia, co przemawia za wykorzystaniem instrumentu decyzji administracyjnej. Stosunek administracyjnoprawny pozwala na należytą kontrolę wykorzystania środków pomocy. Kontrolę wykorzystania środków zapewnia także stosunek cywolnoprawny, zrodzony umową przyznającą środki na określone działanie. Umowa jest instrumentem elastycznym pozwalającym, w ramach zasady swobody umów, na zindywidualizowane określenie sposobu wykorzystania środków, co jest szczególnie ważne, gdy pomoc udzielana jest na cele inwestycyjne. Decyzja winna mieć zastosowanie tam, gdzie udzielana pomoc przybiera postać działań schematycznych, szablonowych; umowa wówczas, gdy potrzebne jest zindywidualizowanie warunków wykorzystania pomocy dla realizacji złożonych procesów, np. procesów inwestycyjnych.

Przy ocenie prawidłowości doboru instrumentów prawnych wdrażających wsparcie konieczne jest uwzględnienie procedur prawnych udzielania pomocy. Procedura powinna zabezpieczać kontrolę spełnienia przesłanek do ubiegania się o uzyskanie pomocy oraz kontrolę prawidłowości wykorzystania tej pomocy. Nadto procedura powinna zabezpieczać prawo beneficjentów do uzyskania pomocy w sytuacji spełnienia prawem określonych przesłanek do jej uzyskania, a także prawo beneficjentów do rozpoznania ewentualnego sporu z organem udzielającym pomocy przez niezawisły sąd.

3. Wydanie decyzji administracyjnej wymaga oczywiście procedury administracyjnej regulowanej przepisami kodeksu postępowania administracyjnego. Natomiast spory wynikające ze stosunków umownych rozpoznają sądy powszechne, stosując reguły kodeksu postępowania cywilnego. Ogólne reguły procedury administracyjnej zostały wszakże zmodyfikowane na mocy art. 21 ustawy z dnia 7.03.2007 r. Do postępowań w sprawach indywidualnych rozstrzyganych w drodze decyzji administracyjnej stosuje się przepisy k.p.a., o ile przepisy ustawy nie stanowią inaczej.

Korekty w modelu postępowania administracyjnego dotyczą głównie pozycji strony w toku postępowania dowodowego. Zgodnie z art. 22 ust. 2 ustawy, w postępowaniu w sprawie dotyczącej przyznania pomocy, organ, przed którym toczy się postępowanie: 
1) stoi na straży praworządności,

2) jest obowiązany w sposób wyczerpujący rozpatrzyć cały materiał dowodowy,

3) udziela stronom, na ich żądanie, niezbędnych pouczeń co do okoliczności faktycznych i prawnych, które mogą mieć wpływ na ustalenie ich praw i obowiązków będących przedmiotem postępowania,

4) zapewnia stronom, na ich żądanie, czynny udział w każdym stadium postępowania; przepisu art. 81 k.p.a. nie stosuje się.

Przytoczony przepis wskazuje jednoznacznie, iż korektury w zastosowaniu k.p.a. polegać mają na próbie zachowania podstawowych zasad postępowania (zasada legalności i praworządności wyrażana w art. 6 i początkowej części art. 7 k.p.a.), przy istotnej modyfikacji reguł postępowania dowodowego (nawet z odstępstwem od zasady prawdy obiektywnej) ${ }^{12}$. Konsekwencje tych zmian będzie musiało wyjaśnić orzecznictwo sądów administracyjnych, albowiem można mieć daleko idące wątpliwości, jakie są istotne różnice w działaniu organu administracji, kiedy organ ten działa na podstawie przepisów prawa (art. 6 k.p.a.), a kiedy jedynie „stoi na straży praworządności” (art. 21 ust. 2 pkt 1 ustawy).

Nakładając na organ administracji publicznej obowiązek rozpatrzenia całego materiału dowodowego w sposób wyczerpujący (art. 22 ust. 2 pkt 2 ustawy), ustawodawca zdecydował się na odejście od zasady prawdy obiektywnej wyrażanej w części 2 art. 7 k.p.a., obligującej organy administracji do podjęcia wszelkich kroków niezbędnych do dokładnego wyjaśnienia stanu faktycznego oraz do załatwienia sprawy, mając na względzie interes społeczny i słuszny interes obywateli. Zwolnienie organu administracji z obowiązku ,podjęcia wszelkich kroków niezbędnych do dokładnego wyjaśnienia stanu faktycznego" oznacza, że ARiMR nie ma obowiązku aktywnego poszukiwania dowodów na poparcie oświadczeń składanych we wniosku przez ubiegającego się o pomoc beneficjenta. W nowym modelu postępowania dowodowego to strony (oraz inne osoby) uczestniczące w postępowaniu są obowiązane przedstawić dowody oraz dawać wyjaśnienia co do okoliczności sprawy zgodnie z prawdą i bez zatajania czegokolwiek; ciężar udowodnienia faktu spoczywa na osobie, która z tego faktu wywodzi skutki prawne (art. 22 ust. 3 ustawy). Przyjęta w ustawie klauzula ciężaru dowodu nie odbiega od klauzuli ciężaru dowodu regulowanej przepisem art. 6 Kodeksu cywilnego. Klauzula ta jest jedną z podstawowych zasad regulacji stosunków między równorzędnymi podmiotami prawa prywatnego w sferze materialnoprawnej i procesowej. Klauzula ta nie przystaje do legislacji dotyczącej procedur stosowanych w rozstrzyganiu stosunków publicznoprawnych. Zamach systemów wsparcia bezpośredniego, Komentarz, Warszawa 2008, s. 48 i n. Komentarz dotyczy art. 3 ustawy wymienionej w tytule Komentarza, jest wszakże w pełni zasadny w stosunku do treści przepisu art. 21 ustawy o wspieraniu rozwoju obszarów wiejskich wobec identycznego brzmienia tych przepisów. 
stosowanie rozkładu ciężaru dowodu przewidzianego w art. $6 \mathrm{kc}$. do relacji występującej pomiędzy AR i MR (decydującą władczo o przyznaniu pomocy) a rolnikiem (wnioskującym o przyznanie wsparcia) zrodzi - jak twierdzą komentatorzy - szereg wątpliwości interpretacyjnych, z którymi zmierzyć się przyjdzie organom odwoławczym i sądom administracyjnym ${ }^{13}$.

Korektury w modelu postępowania administracyjnego zostały wprowadzone „w podobnym zakresie, zarówno w omawianej ustawie, jak i w ustawie o płatnościach w ramach systemów wsparcia bezpośredniego ${ }^{14}$. Stan ten też może budzić wątpliwości. Udzielenie wsparcia bezpośredniego wymaga wydania (corocznie) decyzji administracyjnej przyznającej płatności każdemu rolnikowi posiadającemu grunty wchodzące w skład gospodarstwa rolnego, o łącznej powierzchni działek rolnych nie mniejszej niż 1 ha. Oznacza to konieczność wydania około 1,8 mln decyzji administracyjnych. Tak ogromna liczba decyzji uzasadnia konieczność uproszczenia, usprawnienia i obniżenia kosztów prowadzonych postępowań administracyjnych. Wobec identyczności przesłanek warunkujących przyznanie płatności bezpośrednich, wydane decyzje mogą być oparte na schematach rozstrzygnięć, co pozwala na uproszczenie procedury.

W przypadku decyzji jako instrumentu uruchomiającego wsparcie rozwoju obszarów wiejskich mamy do czynienia z sytuacją częściowo odmienną. Decyzje te nie mają tak masowego charakteru. Są one zróżnicowane co do treści, ponieważ dotyczą 11 rodzajów wsparcia rozwoju obszarów wiejskich. W konsekwencji zróżnicowany jest również przedmiot i zakres postępowania dowodowego. I tu rodzi się pytanie, czy zastosowanie jednolitego schematu uproszczenia postępowania w stosunku do wszystkich decyzji znajduje uzasadnienie. Odpowiedź wymaga pogłębianych badań teoretycznych i empirycznych, pamiętać wszakże należy, że to pełny model postępowania administracyjnego, regulowanego przepisami k.p.a. stanowi gwarancje obiektywnego rozpoznania i rozstrzygnięcia sprawy, mając na względzie interes społeczny i słuszny interes obywateli. Modyfikacje procedury osłabiają pozycję procesową stron postępowania.

Zupełnie nowatorskie rozwiązanie zostało zaproponowane w procedurze udzielania wsparcia na podstawie umowy. „Nowalijka” ta uregulowana została przepisami art. 22 ust. 2 oraz ust. 3 ustawy. Zgodnie z dyspozycją przepisu ust. 2, „do postępowań w sprawach przyznania pomocy na podstawie umowy prowadzonych przez podmioty wdrażające nie stosuje się przepisów Kodeksu postępowania administracyjnego, z wyjątkiem przepisów dotyczących właściwości miejscowej organów, wyłączenia pracowników organu doręczeń i wezwań, udostępniania akt, a także skarg i wniosków. Przepisy art. 21 ust. 2 i 3 stosuje się odpowiednio". Przytoczone sfor- 
mułowanie przepisu art. 22 ust. 2 ustawy wskazuje, iż udzielenie pomocy na podstawie umowy poprzedzane jest postępowaniem quasi-administracyjnym, mającym na celu sprawdzenie, czy spełnione są warunki przyznania takiej pomocy. W tym postępowaniu wstępnym ,nie stosuje się przepisów k.p.a.”, ale w istocie stosuje się k.p.a. tylko w formie zmodyfikowanej, albowiem poprzez wskazanie, iż ,przepisy art. 21 ust. 2 i 3 stosuje się odpowiednio" mamy do czynienia z takim samym modelem postępowania jaki znajduje zastosowanie w sytuacji udzielenia pomocy na podstawie klasycznej decyzji administracyjnej.

Procedura administracyjna znajduje także zastosowanie w sytuacji odmowy przyznania pomocy udzielanej na podstawie umowy. W przypadku, gdy nie są spełnione warunki przyznania pomocy udzielonej na podstawie umowy, podmiot wdrażający informuje wnioskodawcę, w formie pisemnej, o odmowie jej przyznania z podaniem przyczyn odmowy (art. 22 ust. 3). W takim przypadku wnioskodawcy przysługuje prawo wnoszenia do sądu administracyjnego skargi, na zasadach i w trybie określonym dla aktów lub czynności, o których mowa w art. $3 \S 2$ pkt 4 ustawy z dnia 30.08.2002 r. - Prawo o postępowaniu przed sądami administracyjnymi ${ }^{15}$.

Prawdą jest, iż sądy administracyjne sprawując kontrolę działalności administracji publicznej, pod względem zgodności z prawem, orzekają w sprawach skarg na inne niż decyzje administracyjne i postanowienia, akty lub czynności z zakresu administracji publicznej, dotyczące uprawnień lub obowiązków wynikających z przepisów prawa (art. $3 \S 2$ pkt 4 p.p.s.a.). Czy informację o odmowie udzielenia pomocy można uznać za taki akt lub czynność? Kolejny problem wymagający rozważenia to charakter orzeczeń sądów administracyjnych. Sądy te, uwzględniając skargę, orzekają kasacyjnie - uchylają zaskarżony akt administracyjny. Na mocy art. 146 § 1 p.p.s.a., sąd uwzględniając skargę na akt lub czynność, o których mowa w art. $3 \S 2$ pkt 4, uchyla ten akt albo stwierdza bezskuteczność czynności. Czy zatem sąd ma uchylić albo stwierdzać bezskuteczność informacji o odmowie przyznania pomocy? Wydaje się, że w analizowanych sprawach zastosowanie powinien znaleźć przepis art. $146 \S 2$, który stwierdza, że w sprawach, o których mowa w $\S$ 1, sąd może w wyroku uznać uprawnienie lub obowiązek wynikające z przepisów prawa. I tu też rodzi się pytanie, czy wyrok sądowy ma nakładać obowiązek zawarcia umowy z beneficjentem, czy też może - uwzględniając treść przepisu art. 64 kc. - prawomocne orzeczenie sądu stwierdzające obowiązek danej osoby do złożenia oznaczonego oświadczenia woli zastępuje to oświadczenie. To są problemy bardzo istotne dla funkcjonowania systemu wsparcia rozwoju obszarów wiejskich z punktu widzenia ochrony interesów beneficjentów. Osobiście jestem zdania, iż niezbędna jest tutaj interwencja ustawodawcy upraszczająca system przyznania pomocy. Tam, 
gdzie pomoc udzielana na mocy umowy wymaga skomplikowanej oceny warunków jej przyznania oraz kontroli wykorzystania środków, umowa może być poprzedzona decyzją administracyjną zaliczającą beneficjenta do kategorii osób kwalifikujących się do uzyskania pomocy. Rozmiary pomocy, zasady jej udzielenia, kontrolę wykorzystania środków określałaby umowa. Dobór instrumentu prawnego służącego udzieleniu wsparcia - decyzja administracyjna czy umowa cywilnoprawna - winien być poprzedzony oceną, który z mechanizmów jest adekwatny do kontroli spełnienia przesłanek warunkujących uzyskanie pomocy, a jednocześnie zapewnia skuteczną ochronę interesów prawnych beneficjenta, któremu pomoc jest przyznana. 


\section{The Choice of the Legal Instruments of the Development of Rural Areas}

\section{Summary}

The implementation of the Rural Development Programme in Poland in 20072013 is based on the new legislation of the European Union, as well as on the Polish law in form of legislative and administrative provisions, the latter issued by the Minister of Agriculture. In the new legislative framework the existing legal instruments of financial assistance remain in force. It also introduces a range of new procedural provisions, develops the catalog of instruments, as well as emphasizes the application of civil law contract as an organizational instrument of granting financial assistance. The choice of legal instrument granting financial assistance - whether administrative decision or civil law contract - should be preceded by a profound examination giving answer to the question: which of the instruments is more appropriate for controlling compliance with the requirements for financial assistance and, at the same time, for securing legal interests of the beneficiary. 